\title{
TINGKAT STATUS PENCEMARAN BAKTERI SELAMA PENYIMPANAN DI JALUR DISTRIBUSI TELUR AYAM LAYER
}

\author{
Oktavia Mutiarini ${ }^{1}$, Fajar Wahyono ${ }^{2}$ dan Siti Susanti ${ }^{2}$ \\ 1) Mahasiswa Fakultas Peternakan Dan Pertanian Universitas Diponegoro \\ Kampus drh. Soejono Koesoemowardojo Tembalang Semarang 50275 \\ E-mail: oktaviamutiarini@gmail.com \\ ${ }^{2)}$ Fakultas Peternakan dan Pertanian, Universitas Diponegoro \\ Kampus drh. R. Soejono Kusumowardojo Tembalang, Semarang 50275 \\ Diterima: 01 September $2016 \quad$ Disetujui: 28 November 2016
}

\begin{abstract}
ABSTRAK
Penelitian ini bertujuan untuk mengkaji pengaruh penyimpanan pada berbagai tempat pendistribusian telur dalam kurun waktu tertentu untuk mengetahui jumlah total bakteri dan Coliform. Rancangan yang digunakan adalah uji $\mathrm{T}_{\text {test }}$ dan Rancangan Acak Lengkap dengan 4 perlakuan dan 5 ulangan yaitu T0 (tanpa perlakuan); T1 (penyimpanan di konsumen) ; T2 (penyimpanan di peternakan) dan T3 (penyimpanan di pasar), penyimpanan dilakukan selama 4 minggu. Data dianalisis menggunakan $\mathrm{T}$ Test untuk mengetahui pengaruh perlakuan pada jumlah total bakteri dan ANOVA untuk mengetahui perlakuan pada bakteri coliform. Hasil menunjukkan bahwa tingkat status cemaran bakteri T0: $0,86 \pm 0,96$, T1: $19,70 \pm 12,56$, T2: $57,20 \pm 6,61$, dan T3: 50,60 $\pm 34,8\left(10^{4} \mathrm{cfu} / \mathrm{g}\right)$ sedangkan Coliform T0: 16,76 \pm 17,98, T1: 28,08 \pm 22,24, T2: 93,24 \pm 79,10, dan T3: $354 \pm 77,0510^{4}(\mathrm{cfu} / \mathrm{g})$ berpengaruh nyata $(\mathrm{P}<0,05)$ terhadap tempat penyimpanan pendistribusian. Dapat disimpulkan bahwa jumlah total bakteri dan Coliform dipengaruhi oleh suhu, kelembaban, sinar matahari, angina, kontaminan dan penyimpanan.
\end{abstract}

Kata Kunci: kualitas telur, distribusi, total bakteri, coliform

\section{THE LEVEL OF BACTERIA POLLUTION STATUS DURING STORAGE IN THE LAYER CHICKEN EGG DISTRIBUTION LINE}

\begin{abstract}
The purpose of this research is to examine the impact of the egg distribution storage in various places at certain times to find out the amount of bacteria and coliform. The research design used are $T$ Test and random-complete design with four times practice and five times repetition namely TO (without treatment) ; T1 (The storage in consumers) ; T2 (The storage in the farm) ; T3 (The storage in the market). The storage was done within four weeks. The data is analyzed using T test to figure out the impact of the total amount of bacteria and ANOVA to find out the impact towards colifirm bacteria. The result shows that the status level of bacteria pollution T0: $0,86 \pm 0,96, T 1: 19,70 \pm 12,56, T 2: 57,20 \pm$ 6,61, and T3: 50,60 $\pm 34,8\left(10^{4} \mathrm{cfu} / \mathrm{g}\right)$ whereas coliform T0: 16,76 $\pm 17,98, \mathrm{Tl}: 28,08 \pm$ 22,24, T2: 93,24 $\pm 79,10$, and T3: $354 \pm 77,0510^{4}(\mathrm{cfu} / \mathrm{g})$ is truly impact $(P<0,05)$ towards
\end{abstract}


distribution storage places. Conclusion, the total amount of bacteria and coliform is influenced by the temperature, moist, sun light, wind, contaminant and the storage.

Keywords: Egg quality, distribution, total bacteria, coliform

\section{PENDAHULUAN}

Kebutuhan protein hewani di Indonesia dari tahun ke tahun mengalami peningkatan konsumsi telur yang pesat karena meningkatnya jumlah penduduk dan meningkatnya kesadaran akan pentingnya kebutuhan gizi. Konsumsi telur pada tahun 2014 sejumlah 0,086 kg per kapita per minggu (Badan Pusat Statistik, 2014). Masyarakat umumnya lebih memilih telur ayam dari pada daging yang harganya lebih mahal. Oleh sebab itu telur yang dikonsumsi harus memenuhi kriteria persyaratan konsumsi telur. Kriteria konsumsi telur yang telah diperhatikan akan berdampak baik pada masyarakat karena kebutuhan protein yang terpenuhi.

Masyarakat umumnya masih mengkonsumsi telur tanpa memikirkan telur tersebut masih layak untuk dikonsumsi atau tidak. Telur yang disimpan terlalu lama dalam kondisi utuh atau baik dapat disimpan selama 30 hari pada suhu $4-7^{\circ} \mathrm{C}$ dengan kelembaban 60-70 \% (SNI, 2008). Sedangkan telur dalam kondisi pecah harus segera di konsumsi agar tidak terkontaminasi oleh mikroorganisme lain yang membahayakan manusia. Namun telur akan mudah rusak, oleh karena itu perlu mengetahui faktor yang mempengaruhi kualitas telur.

Kualitas telur dapat dipengaruhi oleh umur, jenis strain, faktor lingkungan seperti kelembaban, suhu, waktu penyimpanan, nutrisi pakan dan kontaminasi telur oleh mikroorganisme. Telur yang cepat rusak karena adanya pencemaran oleh mikroorganisme itu perlu diteliti tingkat pencemaran pada proses pendistribusian telur.

Berdasarkan hal tersebut penelitian ini dilakukan untuk mengkaji pengaruh penyimpanan pada berbagai tempat pendistribusian telur dalam kurun waktu tertentu untuk mengetahui jumlah total bakteri dan Coliform. Hasil penelitian diharapkan memberi informasi kepada masyarakat mengenai jumlah cemaran total bakteri dan Coliform terbanyak pada penyimpanan di tempat pendistribusian telur. Hipotesis penelitian ini adalah penyimpanan telur pada tempat yang berbeda di asumsikan akan mempengaruhi jumlah total bakteri dan banyaknya bakteri Coliform.

\section{MATERI DAN METODE}

Penelitian dilaksanakan pada bulan April sampai dengan Mei 2016 di Balai Pelayanan Kesehatan Masyarakat Veteriner (BAPEL KESMAVET). Materi yang digunakan pada penelitian ini adalah telur 20 butir, kertas label yang digunakan untuk memberi label pada telur, rak telur yang digunakan untuk proses penyimpanan telur.

Alat yang digunakan digunakan dilaburatorium adalah plastik, stomacher, pipet, cawan petri, cawan porselin, tabung durham, gelas ukur dan tabung reaksi. Bahan kimia yang digunakan pada saat penelitianberupa Plant Acount Agar (PCA), Buffered Pepton Water (BPW) 0,1\%, SLTB dan Brilliant Green Lactose Bile Broth (BGLBB).

Penelitian dilakukan dalam 4 tahap meliputi tahap persiapan, pengambilan sample, perlakuan dan tahab pengambilan 
data. Tahap persiapan meliputi Mensurvei peternakan ayam layer yang digunakan sebagai tempat penelitian, mensurvei pasar sebagai tempat penyimpanan telur. Memastikan tempat uji laboratorium yang akan digunakan saat melakukan uji total bakteri dan Coliform.

Tahap pengambilan sample dilakukan secara berkala karena telur diambil yang memiliki suhu, kelembaban, induk yang sama. Masing masing perlakuan dengan menggunakan 5 butir telur ayam dan penyimpanan dilakukan dengan menyimpan 8 butir setiap perlakuan.

Tahap perlakuan dimulai dengan menguji langsung telur yang tanpa penyimpanan. Menyimpan masing masing 8 butir telur pada penyimpanan di rumah, peternakan dan pasar yang sama sama waktu penyimpanan selama 4 minggu.

Tahap pengambilan data dilakukaan setelah masing - masih telur telah disimpan selama 4 minggu dengan melakukan uji labolatorium. Pengujian total bakteri dengan melakukan uji Total Plate Count (TPC). Pengujian dilakukan dengan mengambil sample telur sebanyak $25 \mathrm{ml}$ dan masukkan kedalam wadah steril. Tambahkan BPW 0,1 \% kedalam kantong steril, menghomogenkan dengan stomacher selama 1 menit - 2 menit (pengenceran 10$\left.{ }^{1}\right)$ Memindahkan $1 \mathrm{ml}$ suspense pengenceran $10^{-1}$ dalam pipet steril dalam 9 ml BPW untuk mendapatkan pengenceran $10^{-2}$. Membuat pengenceran $10^{-3}, 10^{-4}, 10^{-5}$ dengan metode yang sama. Mengambil 1 $\mathrm{ml}$ suspense dari setiap pengenceran dalam cawan petri secara duplo. Menambahkan 15 ml-20 ml PCA yang telah didinginkan hingga $45^{\circ} \mathrm{C} \pm 1^{\circ} \mathrm{C}$ di masing-masing sample dan putar seperti angka delapan agar tercampur seluruhnya. Menginkubasi pada temperature $34^{\circ} \mathrm{C}-36^{\circ} \mathrm{C}$ selama 24 jam dengan meletakkan cawan pada posisi terbalik. Perhitungan dilakukan setiap seri pengenceran kecuali cawan petri yang berisi koloni menyebar dan pilih koloni yang jumlahnya 25 - 250 (SNI 3926: 2008).

Pengujian Coliform menimbang sample sebanyak $25 \mathrm{ml}$ dan meletakkan kedalam wadah steril. Tambahkan BPW $0,1 \%$ ke dalam kantong steril dan menghomogenkan dengan stromacher selam 1-2 menit sebagai pengenceran $10^{-1}$. Pindahkan $1 \mathrm{ml}$ larutan pengenceran $10^{-1}$ dengan pipet steril kedalam $9 \mathrm{ml}$ BPW $0,1 \%$ untuk mendapatkan pengenceran $10^{-2}$ dengan cara yang sama untuk membuat pengenceran $10^{-3}$. Pipet masing-masing 1 $\mathrm{ml}$ dari setiap pengenceran ke dalam 3 seri tabung LSTB yang berisi tabung durham. Inkubasi pada temperature $35^{\circ} \mathrm{C}$ selama 24 -48 jam. Perhatikan adanya gas yang terdapaat pada tabung durham. Pengujian positif jika terdapat gas pada tabung durham. Pengujian Konfirmasi( peneguhan) dilakukan dengan memindahkan biakan positif dengan menggunakan jarum inokulasi dari setiap tabung LSTB ke dalam tabung BGLBB yang berisi tabung durham. Inokulasi pada temperature $36^{\circ} \mathrm{C}$ selama 24 jam. Pengujian akan terdapat gas bila hasilnya positif. Penggunaan tabel Most Probable Number (MPN) untuk menentukan nilai MPN jumlah tabung BGLBB yang positif sebagai jumlah Coliform per milliliter. Mengkombinasi jumlah tabung yang memperlihatkan hasil positif berdasarkan tabel nilai MPN dengan kombinasi dimulai dari pengenceran tertinggi yang masih menghasilkan tabung positif, pengenceran berikutnya terdapat tabung yang negatif. Kombinasi yang diambil terdiri dari tiga pengenceran (SNI 3926: 2008). 
Rancangan penelitian dilakukan dengan menggunakan uji $T_{\text {Test }}$ dan Rancangan Acak Lengkap (RAL) dilanjutkan dengan uji wilayah ganda Duncan dengan menggunakan 4 perlakuan dan sampel sebanyak 5 butir. Perlakuan terdiri dari: $\mathrm{T} 0=$ tanpa penyimpanan, $\mathrm{T} 1=$ penyimpanan 30 hari di rumah, T2= penyimpanan 30 hari di peternakan dan $\mathrm{T} 3=$ penyimpanan 30 hari di pasar.

Parameter yang diamati dalam penelitian ini adalah jumlah total bakteri dan jumlah bakteri Coliform.

Perhitungan parameter menggunakan rumus sebagai berikut.

1. Uji $\mathrm{T}_{\text {Test }}$

$$
=\frac{\left\lfloor\bar{x}_{1}-\bar{x}_{2}\right\rfloor}{\sqrt{\frac{s_{1}^{2} s_{1}^{2}}{n_{1}}+\frac{n_{1}^{2}}{n_{1}}}}
$$

2. RAL

$$
=\mathrm{Y}_{\mathrm{ij}}=\mu+\alpha_{\mathrm{i}}+\varepsilon_{\text {ij }}
$$

\section{HASIL DAN PEMBAHASAN \\ Total Bakteri}

Hasil penelitian tentang tingkat ststus pencemaran total bakteri pada telur ayam layer yang telah disimpan selama 4 minggu dengan tempat penyimpanan yang berbeda dapat dilihat pada Tabel 1, dan perhitungan statistik pada lampiran 1. Hasil test homogenitas varian dengan uji $F$ max menunjukkan bahwa ragam ke 1 populasi yang dibandingkan berdasarkan hasil pengujian ini, T test yang digunakan adalah $\mathrm{T}$ test dengan asumsi ragam tidak sama.

Tabel 1. Rataan nilai total bakteri telur ayam

\begin{tabular}{cc}
\hline \hline Perlakuan & Rataan jumlah total bakteri \\
\hline Kontrol (T0) & $0,86 \pm 0,96^{*}$ \\
Konsumen (T1) & $19,70 \pm 12,56^{*}$ \\
Peternakan (T2) & $57,20 \pm 6,61^{*}$ \\
Pasar (T3) & $50,60 \pm 34,8^{*}$ \\
\hline
\end{tabular}

* superskrip tanda bintang pada kolom yang sama menunjukkan perbedaan nyata antara masing-masing perlakuan terhadap T0 (Tanpa Penyimpanan) $(\mathrm{P}<0,05)$

Hasil penelitian menunjukkan bahwa rataan julah bakteri semakin berkembang. jumlah rataan bakteri dari terkecil hingga terbesar $\mathrm{T} 0=0,86 \pm 0,96 ; \mathrm{T} 1=19,70 \pm$ 12,$56 ; \mathrm{T} 3=50,60 \pm 34,8$ dan $\mathrm{T} 2=57,20 \pm$ 6,61. Jumlah total bakteri menunjukkan perbedaan yang nyata $(\mathrm{P}<0,05)$ pada masing - masing perlakuan. Penyimpanan menurut SNI 3926 (2008) penyimpanan telur konsumsi pada temperature kamar dengan kelembaban $80-90 \%$ hanya maksimal penyimpanan 14 hari. Faktor yang mempengaruhi jumlah bakteri adalah cahaya matahari (Ariyadi dan Dewi, 2009); angin yang menbawa debu (Idayanti, 2009); suhu (Lubis et al., 2012), kelembaban (Jazil et al., 2013); penjual dan pembeli (Borowo et al., 2013); penyimpanan bersama (Jazil et al., 2013) lama penyimpanan (Darmanto et al., 2013); sanitasi yang kurang baik (Borowo et al., 2013);. Kondisi lapang selama penyimpanan telur yang mampu mempengaruhi kontaminasi dapat dilihat pada Tabel 4. 
Tabel 4. Faktor selama penyimpanan yang mempengaruhi pertumbuhan bakteri pada kontrol dan penyimpanan di konsumen, peternakan dan pasar.

\begin{tabular}{lcclc}
\hline \hline Perbedaan & \multicolumn{3}{c}{ Perlakuan } \\
\cline { 2 - 5 } & $\begin{array}{c}\text { Kontrol } \\
(\mathrm{T} 0)\end{array}$ & $\begin{array}{c}\text { Konsumen } \\
(\mathrm{T} 1)\end{array}$ & $\begin{array}{c}\text { Peternakan } \\
(\mathrm{T} 2)\end{array}$ & $\begin{array}{c}\text { Pasar } \\
(\mathrm{T} 3)\end{array}$ \\
\hline $\begin{array}{l}\text { Suhu } \\
\text { Kelembaban }\end{array}$ & - & Terkendali & Tidak terkendali & Tidak terkendali \\
Cahaya Sinar & - & Terkontrol & Tidak Terkontrol & Tidak Terkontrol \\
Matahari & - & - & Ada & - \\
Angin & - & - & Banyak & - \\
Kontaminasi & - & Sedikit & Sedikit & Banyak \\
Penyimpanan & - & Bersama & Bersama & Bersama \\
\hline
\end{tabular}

T0 adalah adalah sebagai kontrol karena setelah diambil telur langsung diujikan dan hasil masih memenuhi standar telur konsumsi. Hasil uji T0 adalah 0,86 \pm $0,96\left(10^{4} \mathrm{cfu} / \mathrm{g}\right)$, sedangkan $1 \times 10^{5} \mathrm{cfu} / \mathrm{g}$ SNI 2897 (2008). Pengujian T0 tidak ada faktor lain yang mempengaruhi tumbuhnya bakteri. Bakteri yang terdapat pada T0 di mungkinkan adanya kontaminasi terjadi saat telur masih berada didalam kandang. Kontaminasi dari kandang meliputi induk yang terinfeksi, tempat ayam bertelur, kotoran, saat mengambil sample dan peternak. Menurut Lubis et al., (2012) bakteri dapat masuk dan mencemari telur melalui induk yang terinfeksi dan faktor lingkungan Pengujian langsung yang dilakukan setelah pengambilan langsung dikemas sehingga telur dalam keadaan an aerob. Menurut Knactger (2011) beberapa bakteri memerlukan oksigen (aerob) untuk metabolisme. Bakteri tidak akan tumbuh karena mikroorganisme sangat sulit untuk berkembang.

T1 merupakan perlakuan yang dilakukan di rumah konsumen dan sudah tidak memenuhi kriteria sebagai telur konsumsi karena jumlah total bakteri lebih dari standart, jumlah bakteri 19,70 $\pm 12,56$ $\left(10^{4} \mathrm{cfu} / \mathrm{g}\right)$. Kriteria telur konsumsi yang baik harus disimpan pada suhu $4^{\circ}-7^{\circ} \mathrm{C}$ dengan kelembaban $60-70 \%$ dan waktu penyimpanan maksimal selama 30 hari setelah ditelurkan. Faktor yang mempengaruhi pertumbuhan total bakteri perlakuan di rumah konsumen meliputi suhu, kelembaban, penyimpannan dan cemaran. Suhu dirumah (T1) terkendali yang berarti suhu akan mudah terkontrol, sehingga telur tidak mudah terkontaminasi oleh beberapa mikroorganisme (bakteri, pathogen) yang mampu merusak telur. Suhu di dalam rumah umumnya suhu kamar yang mampu menstabilkan mikroorganisme. Idayanti et al., (2009) berpendapat bahwa pada suhu kamar aktifitas metabolisme mikroorganisme kurang baik sehingga pertumbuhan dan perkembang biakan tidak stabil yang akibatnya total mikroba di dalam telur tidak berkembang. Penyimpanan pada suhu kamar lebih baik disbanding pada suhu peternakan dan pasar. Menurut Lubis et al (2012) penyimpanan pada suhu yang terkendali dapat memperlambat aktifitas metabolisme, serta menghambat pertumbuhan bakteri dan hilangnya kadar air dalam bahan pangan. Penyimpanan dilakukan dengan penyimpanan bersamaan dengan bahan lain seperti bumbu dapur (bawang merah, bawang putih, garam, merica dll). Semakin banyak bahan yang tersimpan dalam ruangan yang sama tingkat kontaminasi semakin banyak karena dari asal bahan maupun bau mampu mempengaruhi bahan lain. Menurut Jazil et 
al., (2013) lama penyimpaan bersamaan dapat meningkatkan kerusakan cangkang maupun isi telur. Pencemaran bakteri dirumah konsumen ada tetapi tidak banyak faktor yang mempengaruhi.

T3 adalah penyimpanan di pasar yang memiliki faktor pertumbuhan bakteri terbanyak ke 2 dari penyimpanan di rumah konsumen, peternakan dan pasar, jumlah total bakteri 50,60 $\pm 34,8\left(10^{4} \mathrm{cfu} / \mathrm{g}\right)$. Faktor yang mempengaruhi pertumbuhan bakteri meliputi suhu, kelembaban, kontaminasi manuasia, penyimpanan bersama dan pencemaaran. Suhu dan kelembaban umumnya menjadi factor utama dalam pertumbuhan bakteri karena pada penyimpanan dirumah konsumen juga terjadi dan masih terkontrol. Sedangkan suhu daan kelembaban pada pasar tidak terkontrol. Suhu tidak terkendali karena pada tempat tersebut kondisi suhu tergantung pada kondisi lindungkungan sekitar. Kondisi lingkungan yang berubahubah akan akan mengakibatkan pencemaran yang berganti. Menurut Idayanti et al (2009) telur akan terkontaminasi oleh mikroba setelah penyimpanan pada suhu yang tidak terkendali yang akan mengakibatkan telur tersebut mengalami kerusakan. Kerusakan pada telur terjadi ketika penyimpanan telur dilakukan pada suhu diatas $25^{\circ} \mathrm{C}$. Pasar merupakan tempat yang paling banyak terjadinya kontaminasi antara satu dengan yang lain. Umumnya panjual dan pembeli ketika di pasar tidak memperhatikan kebersihanya ketika berkunjung kepasar. Masyarat saat memilih telur juga akan memilih telur yang akan dibeli sehingga pada satu telur biasanya sudah banyak terpegang oleh manusia. Masyarakat satu sama lain akan membawa cemaran yang berbeda pada satu butir telur. Menurut Borowo et al., (2013) penjual dan pembeli yang berdatangan dan sangat banyak akan mempengaruhi sanitasi bahan pangan yang mengakibatkan kontaminasi silang bakteri pindah dari satu tempat ke tempat lain. Kontaminasi berpengaruh pada tingkat pencemaran telur, semakin banyak manusia memungkinkan akan terjadi pencemaran semakin banyak pula. Penjual melakukan bersamaan dengan bahan pokok lain seperti beras, kacang tanah, bawang merah, bawang putih, dan lain- lain. Semakin banyak bahan yang tersimpan dalam ruangan yang sama tingkat kontaminasi semakin banyak karena dari asal bahan maupun bau mampu mempengaruhi bahan lain. Kontaminasi pencemaran di pasar terjadi karena sanitasi yang kurang baik, saat transportasi penjual dan pembeli, pencampuran bahan lain, suhu dan kelembaban. . Menurut Triyoso (2004) sumber pencemaran pada telur berasal dari ungas yang sakit, alas kandang, wadah telur, debu, tanah atau lingkungan, penyimpanan, sanitasi, dan kebersihan pekerja. Pencemaran akan mempengaruhi jumlah total bakteri yang ada pada telur

T2 merupakan tempat tempat pencemaran yang dilakukan di peternakan yang memiliki faktor pengaruh pertumbuhan bakteri terbanyak dibandingkan dengan penyimpanan di rumah konsumen dan pasar dengan jumlah total bakteri $57,20 \pm 6,61\left(10^{4} \mathrm{cfu} / \mathrm{g}\right)$. Faktor yang mempengaruhi pertumbuhan bakteri meliputi, suhu, kelembaban, cahaya matahari, angin, kontaminasi manusia, penyimpanan dan cemaran. Suhu dan kelembaban sama-sama tidak terkontrol sehingga mikroorganisme dapat berkembang dengan baik. Cahaya matahari yang terdapat dipeternakan yang memiliki bangunan sederhana dan dinding berlubang sehingga sinar matahari dapat langsung mengenai telur ayam. Cahaya matahari yang mengenai telur ayam dapat 
mengurangi aktifitas perkembangnya mikroorganisme.

Menurut Ariyadi dan Dewi (2009) yang menyatakan bahwa cahaya matahari mampu membunuh mikroorganisme karena sinar ultraviolet karena mempunyai efek letal terhadap sel-sel mikroorganisme. Sinar ultraviolet efektif untuk mengendalikan mikroorganisme pada permukaan yang terpapar langsung atau mikroba berada di dekat permukaan medium yang transparan. Menurut Akbar (2008) absopsi sinar ultraviolet dalam sel terjadi pada asam nukleat maka diperkirakan mekanisme utama kerusakan sel oleh sinar ultraviolet pada ribosom, sehingga mengakibatkan terjadinya mutasi atau kematian sel.

Peternakan merupakan tempat yang paling banyak terkontaminasi oleh angin. Angin bersifat pembawa bahan lain yang dapat mencemari telur. Menurut Idayanti (2009) angin akan membawa debu dan mengakibatkan debu menempel pada cangkang telur sehingga mikroorganisme dapat masuk. Kerusakan akan bermula pada masuknya mikroba melalui pori-pori telur sehingga telur akan mengalami kerusakan. Menurut Notoadmojo (2002) kerusakan pada telur terjadi ketika mikroba menembus pada kulit telur. Penyimpanan di peternakan terjadi kontaminasi oleh peternak, pekerja kandang, hewan, penjual dan pembeli. Selain itu penyimpanan dengan meletakkan telur bersamaan dengan telur lama juga mempengaruhi mikroorganisme. Pencemaran di peternakan terjadi paling banyak karena adanya kontaminasi dari kotoran. Menurut Pramesti (2013) kualitas telur yang baik sangat berpengaruh pada suhu, kelembaban, umur dan kontaminasi telur mikroba akibat lingkungan sekitar. Faktor yang mempengaruhi pertumbuhan bakteri selama penyimpanan meliputi suhu, kelembaban, sinar matahari, angin, kontaminan, dan penyimpanan.

\section{Jumlah Bakteri Coliform}

Hasil penelitian tentang tingkan status pencemaran bakteri Coliform pada telur ayam layer yang telah disimpan selama 4 minggu dengan tempat penyimpanan dirumah konsumen, peternakan dan pasar dapat dilihat pada Tabel 5.

Tabel5. Rataan nilai total bakteri Coliform telur ayam tanpa penyimpanan, penyimpanan di konsumen, peternakan dan pasar.

\begin{tabular}{cc}
\multicolumn{2}{c}{ penyimpanan jumlah bakteri Coliform $\left(10^{4} / \mathrm{cfu} / \mathrm{g}\right)$} \\
\hline Perlakuan & $16,76 \pm 17,98^{\mathrm{a}}$ \\
\hline Kontrol (T0) & $28,08 \pm 22,24^{\mathrm{a}}$ \\
Konsumen (T1) & $93,24 \pm 79,10^{\mathrm{b}}$ \\
Peternakan (T2) & $354 \pm 77,05^{\mathrm{c}}$ \\
Pasar (T3)
\end{tabular}

a, b, c Superskrip yang berbeda pada kolom yang sama menunjukkan perbedaan yang nyata $(\mathrm{P}<0,05)$

Bakteri Coliform merupakan bakteri gram negative yang memiliki banyak batang yang dapat menfermentasi laktosa, gram negatif, bersifat an aerob dan aerob, dapat tumbuh pada media yang mengandung garam empedu, mampu memfermentasi laktosa untuk menghasilkan asam dan gas pada suhu $35-37^{\circ} \mathrm{C}$, tidak berspora dan merupakan bakteri misofilik. Menurut Djaka et al (2013) bakteri golongan mesofilik tumbuh pada suhu $10^{\circ} \mathrm{C}$ - $47^{\circ} \mathrm{C}$, dapat hidup dalam tanah, tubuh 
hewan vertebrata tetapi suhu optimum pertumbuhanya berkisar $30-45^{\circ} \mathrm{C}$ tergantung masing-masing spesies. Contoh bakteri Coliform adalah Esherechia coli yang merupakan Coliform fekal yang berasal dari kotoran manusia, Citrobacter, Enterobacter merupakan Coliform non fekal yang berasal dari hewan dan tumbuhan mati (Batt dan Tortorello, 2014). Faktor pembawa bakteri Coliform berupa angin, hewan lain dan manusia.

Hasil penelitian menunjukkan bahwa jumlah bakteri Coliform tanpa penyimpanan (T0) dengan penyimpanan di rumah konsumen tidak terdapat perbedaan nyata dan masih memenuhi kriteria standar. Tingkat cemaran bakteri Coliform terjadi peningkatan pada penyimpanan di peternakan (T3) 93,24 \pm 79,10; dan di pasar (T2) sebanyak $354 \pm 77,05 \quad \mathrm{cfu} / \mathrm{g}$. Peningkatan jumlah bakteri tertinggi terjadi pada penyimpanan di pasar. Hal ini menunjukkan bahwa peningkatan bakteri Coliform terjadi karena tingkat sanitasi pasar yang kurang baik karena sampah yang beterbangan atau yang tertiup angin dapat menempel pada telur. Penempelan yang terjadi mengakibatkan kotoran, sampah dan debu menempel pada cangkang sehingga semakin lama akan dapat masuk ke dalam telur melalui pori-pori. Kebersihan lingkungan sekitar dan telur sendiri perlu diperhatikan karena mikroba dapat tumbuh dan berkembang dengan kondisi tertentu. Menurut Aereta et al. (2014) hygiene mempengaruhi kualitas yang dapat menyebabkan kontaminasi mokrobiologis. Faktor pembawa seperti hewan juga dapat mempengaruhi kualitas telur. Ketika malam hari dan kondisi pasar gelap tikus mulai melakukan aktivitasnya dengan memakan atau menginjakkan kakinya ke dagangan yang dijual oleh penjual. Selain tikus, hewan yang merupakan faktor pembawa seperti serangga juga dapat menyebabkan terjadinya kontaminasi. Contohnya kecoa yang dapat yang dapat menularkan bakteri pada bahan makanan. Menurut Fauzi et al. (2014) kecoa biasa berperan sangat penting sebagai vaktor mekanik bagi beberapa mikro organisme pathogen, sebagai inang perantara. Manusia merupakan faktor terbesar terjadinya kontaminasi, ketika penjual atau pembeli yang memegang telur secara berulang-ulang pada satu telur ke telur yang lain yang terdapat kotoran ternak akan menyebabkan telur terkontaminasi. Hal ini erat kaitannya dengan terjadinya kontaminasi pada bahan makanan, karena manusia merupakan sumber potensial mikroba. Menurut Aereta et al. (2014) penjamah adalah sumber utama dan potensial dalam kontaminasi dan permindahan mikroorganisme.

\section{SIMPULAN DAN SARAN Simpulan}

Jumlah total bakteri dan Coliform selama penyimpanan dipengaruhi oleh suhu, kelembaban, sinar matahari, angin, kontaminan dan penyimpanan.

\section{Saran}

Tingkat sanitasi perlu diperhatikan saat penyimpanan untuk meminimalisir jumlah total bakteri dan Coliform.

\section{DAFTAR PUSTAKA}

Aereta. A. N, Eram T.P dan Mardiana. 2014. Hubungan hygiene pedagang dan sanitasi dengan kontaminasi Salmonella pada daging ayam potong. Fakultas Ilmu Keolahragaan. Universitas Negeri Semarang. Semarang. 3(4) 
Akbar, Teguh A. 2008. Pengaruh Cahaya Terhadap Senyawa Anti Bakteri Dari Chetoceros gracilis. Skripsi. Institut Pertanian Bogor, Bogor.

Al, Eis. M. 201. Upaya menjaga eksistensi pasar tradisional studi revitalisasi pasar piyungan Bantul. Fakultas Dakwah. Universitas Islam Negeri Sunan Kalijaga. Yogyakarta

Ariyandi. T dan Dewi S.S. 2009. Pengaruh sinar ultra violet terhadap pertumbuhan bakteri Bacillus sp. Sebagai bakteri kontaminan. Universitas Muhammadiyah

Badan Pusat Statistik (BPS), diakses dari http.//www.bps.go.id/, diakses pada tanggal 26 Agustus 2016

Badan Standarisasi Nasional (BSN). 2008. SNI 3926 : Telur Ayam Konsumsi. BSN, Jakarta.

Bambang. A. G, Fatimawa dan S. K. Novel. 2014. Analisis cemaran bakteri Coliform dan identifikasi Esherichia coli pada air isi ulang dari depot di kota Manado. Fakultas Matematika dan Ilmu Pengetahuan Alam. Universitas Sam Ratulangi. Manado. 3(3)

Batt. K.G dan Tortorello, M.L. 2014.

Encyclopedia of Food

Microbiology. Elsevier. London. 987

Borowo, J., I Made Sukada dan I Gusti Ketut S. 2013. Perbandingan jumlah bakteri Coliform pada telur ayam buras yang dijual dipasar bersanitasi baik dan buruk. Jurnal Indonesia Medicus Veterinus 2(3):269-280

Darmanto K.P., Achmanu, dan E. Sudjarwo. 2013. Pengaruh suhu dan lama simpan telur tetas itik hibrida terhadap daya tetas dan kematian embrio. Jurnal Ilmiah Peternakan. 1 (1) : 65-71

Djoko. Mas. R. Rhiyan M. S dan I.G. Ketut Suarjana. 2013. Pengaruh suhu dan lama penyimpanan telur ayam local terhadap jumlah Coliform. Faktor Kedokteran Hewan. Universitas Udayana. Denpasar. 1(3) hal. 394407

Fauzi. F.M, Sulistiani dan Retno. H. 2014. Uji efektivitas ekstrak bakteri simbion lamun enhalus sp. Sebagai bioinsektisida pada kecoa blatella germanica di laboratorium. Fakultas Kesehatan Masyarakat. Universitas Diponegoro. Semarang. 2(2)

Idayanti, S. Darmawati dan Ulfa N. 2009. Perbedaan variasi lama simpan telur ayam pada penyimpanan suhu almari es dengan suhu kamar terhadap total mikroba. Fakultas Ilmu Keperawatan dan Kesehatan Universitas Muhammadiyah Semarang. Semarang. 2(1):19-26

Jazil, N., A Hintono dan S. Mulyani. 2013. Penurunan kualitas telur ayam ras dengan intensitas warna coklat kerabang berbeda selama penyimpanan. Fakultas Peternakan dan Pertanian. Universitas Diponegoro. Semarang 2(1):43-47

Knachtger, P.L. 2011. Food Safety Theory and Practice. East Corolina University

Lubis. H.A, Gusti . K. S, dan Mas D. R. 2012. Pengaruh suhu dan lama penyimpanan telur ayam kampung terhadap jumlah Echerichia coli. Fakultas Kedokteran Hewan. 
Universitas Udayana. Denpasar. 1(1) hal: 144-159

Mansauda KLR, Fatimawati dan Kojong N. 2014. Analisis cemaran bakteri Coliform pada saus tomat jajanan bakso tusuk yang beredar di Manado. Jurnal Ilmiah Farmasi. Universitas Sam Ratulangi. 3 (2): 110

Notoadmojo S. 2002. Metodologi Penelitian Kesehatan, Jakarta.

Nurcholis, D. Hastuti dan B. Sutiyono. 2009. Tatalaksana pemeliharaan ayam ras petelur periode layer di popular farm desa kuncun kecamatan Mijen kota Semarang. Fakultas Peternakan dan Pertanian. Universitas Diponegoro. Semarang 5(2):38-49

Nurullaili dan Wijayanto, Andi. 2013. Analisis faktor - faktor yang mempengaruhi loyalitas konsumen Tupperware. Fakultas Ilmu Sosial dan Politik. Universitas Diponegoro. Semarang. 2(1)

Pramesti, Vera W. 2013. Daya antibakteri albumen telur ayam kampung (Gallus domesticus) dan ayam kate (Gallus bantem) terhadap spesies bakteri Coliform fekal pada cangkang telur. Universitas Negeri Malang. Malang 1(4):365-374

Septika, E. R., D. Septinova dan K. Nova. 2013. Pengaruh umur telur persilangan itik tegal dan mojosari dengan penetasan kombinasi terhadap fertilitas dan daya. Jurnal ilmiah peternakan terpadu 1 (13): $31-36$.

Suherman., D. 2005. Pengaruh Faktor Manajemen Terhadap Kepecahan
Telur. Poultry Indonesia, Edisi 302. Jakarta

Treyens, C., 2009. Bacteria and Private Wells., pp. 19-22. Available from: www.nest.wvu.edu

Troyoso, B 2004. Analisis Kausalitas Antara Ekspor dan Pertumbuhan Ekonomi di Negara Asian. Fakultas Ekonomi. Universitas Sumatera Utara, Medan

Tugiyanti, E dan Iriyanti, 2012. Kualiatas eksternal telur ayam petelur yang mendapat ransum dengan penambahan tepung ikan fermentasi menggunakan isolate produser antihistamin. Jurnal Aplikasi Teknologi Pangan. 1(2)

Yoga, M. A., Bambang A. $\mathrm{N}$ dan B. Hartono. 2014. Efisiensi pemasaran telur ayam ras di kecamatan Ringinrejo kabupaten Kediri. Fakultas Peternakan. Universitas Brawijaya. Malang 